\title{
CONSCIÊNCIA E ALTERIDADE EM L'ÊTRE ET LE NÉANT, DE JEAN-PAUL SARTRE
}

\author{
Nuno P. Castanheira \\ (Universidade de Lisboa)
}

Publicada pela primeira vez em 1943, a obra de Jean-Paul Sartre L'être et le néant. Essai d'ontologie phénoménologique ${ }^{1}$ resulta de um esforço do seu autor para, partindo dos métodos da fenomenologia e procurando alargar os seus horizontes, estabelecer uma ontologia fenomenológica ou ontologia da consciência. Nesse sentido, Sartre vai adoptar uma concepção determinada do que a consciência seja, desenvolvendo a partir dessa mesma concepção do ser da consciência uma análise do significado da alteridade para a consciência, temática que constituirá o cerne do texto que aqui apresentaremos.

A questão em torno da alteridade apresenta-se como uma problemática fundamental na fenomenologia, enquanto método de dilucidação dos actos conscientes, na medida em que visa determinar a nossa experiência de algo que não é uma coisa, mas um outro eu, isto é, um outro sujeito. Para tal, impõe-se uma determinação ou fixação não só do modo da doação do outro à consciência, da entrada do outro na experiência da consciência pessoal - na minha consciência -, mas também, e principalmente, do sentido dessa experiência para mim.

No caso de Sartre, a determinação do modo e do significado da doação de um outro $e u$ à consciência surge no horizonte da questão acerca da constituição da própria consciência enquanto ego, baseada na sua tese, exposta em La Transcendance de l'Ego ${ }^{2}$, de que o $e u^{3}$ está numa relação

1 Sartre, Jean-Paul, L'être et le néant - Essai d'ontologie phénoménologique, Éditions Gallimard, Paris, France, 2003 (1ère Édition 1943) - daqui em diante E.N.. As secções citadas ao longo deste estudo correspondem a traduções nossas do original em francês.

2 Sartre, Jean-Paul, A Transcendência do ego seguido de Consciência de Si e Conhecimento de Si, tradução e introdução de Pedro M.S. Alves, Edições Colibri, Lisboa, Portugal, 1994 - referido, daqui para a frente, como T.E..

3 Devido à dificuldade de tradução da palavra moi, pólo dos actos de consciência,

Philosophica, 33, Lisboa, 2008, pp. 43-74 
de transcendência com a consciência, ou seja, na tese que afirma que a consciência não é habitada por um ego, ela não tem um eu até que este se constitua como objecto para ela, tal como os restantes objectos do mundo.

Para Sartre, a questão fundamental é saber como pode a consciência constituir, como seu objecto, um ego - isto é, como um objecto entre outros, mas cuja experiência é, para a consciência, diferente da experiência que faz daqueles -, para, seguidamente, afirmar a sua identidade com ele, isto é, para o ser.

A relação da alteridade com a constituição da consciência como ego está fundada na contemporaneidade dessa constituição com o aparecimento do outro no mundo circundante. Desse modo, concentrámos a nossa atenção na Terceira Parte de L'être et le néant, mais especificamente no seu capítulo primeiro, intitulado L'existence d'autrui, e na secção acerca do olhar, tendo como objectivo compreender de que modo Sartre aborda esta problemática, mas também mostrar que algumas das suas opções teóricas inviabilizam uma verdadeira determinação do alcance da experiência da alteridade para a consciência.

Descrevemos a realidade-humana a partir das condutas negativas e do cogito. Descobrimos, seguindo esse fio condutor, que a realidade-humana era-para-si. Isso é tudo o que ela é? ${ }^{4}$

No seguimento desta questão, Sartre começa a sua exposição do ser-para-outrem. Conquanto esse seja o objecto do presente estudo, parece-nos impossível de realizar sem que, antes de mais, compreendamos qual é o significado do ser-para-si e o que é a realidade-humana a que Sartre aqui se refere. Como tal, detenhamo-nos um pouco sobre esse tema.

Para Sartre, a consciência só pode ser entendida como uma identidade entre o seu ser e o seu aparecer, isto é, a consciência só existe na medida em que aparece e toda a existência consciente só existe enquanto é consciência de existir:

Com efeito, a existência da consciência é um absoluto porque a consciência está consciente dela mesma. Isto quer dizer que o tipo de

seguimos a sugestão que aparece numa nota à tradução portuguesa de T.E. (p. 46), utilizando a palavra portuguesa $e u$. Nas ocasiões em que exista uma ambiguidade ou uma presença simultânea de je e de moi que possa comprometer o seu sentido, colocaremos entre parênteses a palavra na língua original; referimos ainda que, devido ao estilo de escrita adoptado por Sartre em E.N., frequentemente redigido na primeira pessoa, algumas vezes a palavra moi não é traduzida por $e u$, mas por mim, nomeadamente nas citações do texto sartriano.

${ }^{4}$ E.N., p. 259. 
existência da consciência é o de ser consciência de si. E ela toma consciência de si enquanto ela é consciência de um objecto transcendente. Tudo é, portanto, claro e lúcido na consciência: o objecto está face a ela com a sua opacidade característica, mas ela, ela é pura e simplesmente consciência de ser consciência desse objecto, é a lei da sua existência. É preciso acrescentar que esta consciência de consciência - fora os casos de consciência reflectida, sobre os quais falaremos daqui a pouco - não é posicional, o que quer dizer que a consciência não é para si mesma o seu objecto. O seu objecto está, por natureza, fora dela e é por isso que, por um mesmo acto, ela o põe e o apreende. Ela mesma não se conhece senão com interioridade absoluta. Designaremos tal consciência como consciência do primeiro grau ou irreflectida. ${ }^{5}$

Só esta imanência da consciência a si mesma permite a Sartre empreender o projecto de uma ontologia da consciência em E.N.; é apenas porque para a consciência ser é aparecer, porque "ela permanece, portanto, um "fenómeno" no sentido muito particular em que "ser" e "aparecer" são apenas um" e porque "toda ela é ligeireza, toda ela é translucidez" que Sartre pode passar da fenomenologia à ontologia.

Para Sartre, só uma concepção do ser da consciência como o seu aparecer pode salvaguardar a espontaneidade que a caracteriza e que, uma vez perdida, teria como consequência o abandono do ponto de vista que toma a consciência como um absoluto não substancial, sem opacidade, uma pura transparência. A consciência é, para Sartre, um absoluto porque existe por si, não tem anteriores, é incondicionada. Assim, a consciência é sempre consciência posicional de qualquer coisa e consciência não-posicional de si e se, para a consciência, o ser é idêntico ao aparecer, isto implica que a consciência é, na sua origem, presença a algo dela distinto, um em-si caracterizado pela identidade indiferenciada, pela positividade e pela opacidade, do qual tem um saber imediato, sem que tenha um conhecimento do seu próprio ser como objecto, mas apenas não-teticamente.

De acordo com a própria exposição de Sartre, a consciência é presença a si, ou seja, é uma relação interna do ser que está presente com os seres aos quais está presente, existindo aí, fora de si, no ser de um objecto como não sendo esse objecto. A esta presença do ser da consciência ao ser enquanto tal, enquanto objecto, como um ser que não é o seu, chama Sartre Para-si; a consciência caracteriza-se, então, como Para-si, como perpétuo reenvio de um acto ontológico pelo qual o em-si se degrada perpetuamente em presença a si; o Para-si determina-se perpetuamente a

5 T.E., p. 48. 
não-ser o em-si, fundando-se a si mesmo a partir do em-si e contra o em-si, como não-coincidência.

Mas esta não-coincidência como marca do Para-si ou da consciência não está isenta de problemas.

A concepção de consciência enquanto diferença de si a si não encerra, se tomada isoladamente, problemas, pois se a coincidência entre a consciência e o seu si - ou ser - fosse o caso, não existiria diferença entre a consciência e o em-si do qual ela se separa na afirmação da sua existência; ela seria absoluta indistinção e identidade, arruinando o seu carácter intencional, a sua relação a si enquanto consciência de objecto.

O problema reside na consistência de uma concepção da consciência como presença a si, caracterizada pela não-coincidência entre a consciência e o seu si - ou ser - como surgindo para lá do objecto de que é consciência e, simultaneamente, que conserve a identidade entre ser e aparecer. O Si do Para-si é aquilo que a consciência tem a ser para lá do ser que lhe está presente, aquilo que falta à consciência para que ocorra a coincidência com o seu ser, e é nesta ambiguidade - que marca a concepção sartriana de consciência e do ser que lhe é próprio - que residem as dificuldades da sua compreensão.

A identidade entre ser e aparecer tem uma dupla face:

- por um lado, a consciência só é enquanto aparece, o que, como vimos, não representa qualquer obstáculo a esta concepção da consciência;

- mas, por outro lado, o sentido propriamente sartriano desta concepção da consciência é a afirmação de que não resta, para além deste ser que ela é, mais nenhum ser que lhe possa ser atribuído.

Partindo desse carácter duplo da consciência para Sartre, a questão que logo surge é a seguinte: se o que aparece à consciência, à distância, é o seu $\mathrm{Si}$ - aquilo que consciência tem a ser para coincidir com o seu ser-, mas, por outro lado, o seu ser coincide com o seu aparecer, então estamos diante de um paradoxo, pois não se compreende como pode a consciência ser, simultaneamente, adequação entre ser e aparecer, e desadequação de si a si.

A exigência de uma consciência translúcida, pura espontaneidade ou liberdade, que está na base desta concepção de consciência, faz surgir esta questão fundamental, à qual Sartre procura responder do seguinte modo:

Introduzir na unidade de um cogito pré-reflexivo um elemento qualificado exterior a esse cogito, isso seria quebrar-lhe a unidade, destruir-lhe a translucidez; haveria, então, na consciência qualquer coisa da qual ela não seria consciência, e que não existiria em si mesmo como consciência. A separação que separa a crença dela mesma 
não se deixa nem captar, nem mesmo conceber à parte. Procuremos revelá-la, ela esvanece-se: nós encontramos a crença como pura imanência. Mas se, ao contrário, quisermos captar a crença enquanto tal, então a fissura está lá, aparecendo quando não a queremos ver, desaparecendo quando procuramos contemplá-la. Essa fissura é, por isso, o negativo puro. A distância, o lapso de tempo, o diferendo psicológico podem ser captados neles mesmos e encerram, como tal, elementos de positividade, eles têm uma simples função negativa. Mas a fissura intraconsciente é um nada fora daquilo que ela nega e não pode ter ser senão na medida em que não a vemos. Esse negativo que é nada (néant) de ser e poder nadificante em conjunto, é o Nada. ${ }^{6}$

A falácia de base desta resposta de Sartre é evidente, pois a translucidez da consciência, cuja necessidade se pretendia demonstrar, serve de argumento maior para a sua manutenção, falhando assim uma problematização real da questão.

Para clarificar esta fissura que se instala no seio da própria consciência é necessário que compreendamos o que é este Nada, o que é este ser porque ele é, ainda que não-sendo - que não tem a positividade de uma coisa e que é o próprio fundamento da relação a si, do Para-si. Este Nada é uma não-coincidência instalada no seio da própria consciência, separando-a de si mesma. $\mathrm{O}$ que caracteriza esta não-coincidência, enquanto subjacente à consciência de si, é a capacidade de nadificar, capacidade estruturante da interpretação sartriana da intencionalidade.

De acordo com a interpretação que Sartre faz da intencionalidade, em todo o acto de consciência há uma consciência não-tética de si, e essa consciência de si resulta do facto de a consciência não ser, para ela mesma, isso de que é actualmente consciência. Assim, ainda que apenas como poder nadificante que não se deixa reduzir ao em-si, a consciência é alguma coisa, ascendendo o próprio Nada ao estatuto de ser. Diz-nos Sartre:

A estrutura de base da intencionalidade e da ipseidade é a negação, como relação interna do Para-si à coisa; o Para-si constitui-se de fora, a partir da coisa como negação dessa coisa; assim, a sua primeira relação com o ser em si é a negação; ele 'é' sob o modo do Para-si, ou seja, como existindo disperso enquanto se revela a si mesmo como não sendo o ser. Ele escapa duplamente ao ser, por desagregação íntima e negação expressa. E o presente é precisamente essa negação do ser, essa evasão do ser na medida em que o ser está aí como isso de que nos evadimos. O Para-si está presente ao ser sob a forma de fuga; o presente é uma fuga perpétua em face do ser. ${ }^{7}$

${ }^{6}$ E.N., p. 114.

${ }^{7}$ E.N., p. 158. 
E continua, algumas páginas adiante:

Não esqueçamos que o Para-si, na medida em que se presentifica ao ser para dele fugir, é uma carência. O Possível é isso de que o Para-si carece para ser si ou, se preferirmos, a aparição à distância disso que eu sou. Captamos, desde logo, o sentido da fuga que é presença: ela é fuga ao encontro do seu ser, ou seja, ao encontro do si que ela será por coincidência com aquilo que lhe falta. ${ }^{8}$

Assim, o ser da consciência constitui-se, para Sartre, como um perpétuo reenvio, como um ser que se coloca permanentemente em questão e que se caracteriza como carência, como falta de ser, em virtude da separação ou degradação imediata da coincidência do ser em relação a si que constitui a presença. A este ser chama Sartre realidade-humana, enquanto ser que é, no seu ser e para o seu ser, fundamento de um nada no interior do próprio ser ${ }^{9}$.

Mas o que é esta carência ou falta de ser que caracteriza a realidade-humana ou Para-si?

Desde logo, a sua estrutura trinitária:

- em primeiro lugar, é aquilo que falta, o carecido;

- em segundo lugar, o que carece ou existente;

- em terceiro e último lugar, uma totalidade que foi desagregada pela carência e cuja restauração ocorreria através da síntese do carecido e do existente.

A caracterização da realidade-humana como carência é, de acordo com Sartre, atestada pela existência do desejo, perspectivado como arrancamento ou escape a si mesmo ao encontro do objecto desejado. Assim, enquanto desejo, a realidade-humana é a sua própria superação ao encontro disso de que carece, ela supera-se, arranca-se a si mesma ao encontro do ser que ela seria se, em vez de ser nada, fosse aquilo que é.

Assim e desde logo, a realidade-humana, enquanto perpétuo questionar do seu ser, capta-se como incompletude de ser, como um ser que só é enquanto não-é, como um perpétuo adiar da sua realização ontológica, uma vez que essa totalidade a que ela está presente enquanto carência é a sua totalidade, ou o Si. Em suma, a realidade-humana é projecto de ser.

Sartre oferece-nos um exemplo que ilustra esta dinâmica:

Por exemplo, se eu digo que a lua não está cheia e que lhe falta um quarto, eu faço esse juízo sobre uma intuição plena de um crescente de lua. Assim, aquilo que é entregue à intuição é um em-si que, nele

${ }^{8}$ E.N., p. 161.

${ }^{9}$ E.N., p. 115. 
mesmo, não é nem completo nem incompleto, mas que é aquilo que é muito simplesmente, sem relação com outros seres. Para que esse em-si seja captado como crescente de lua, é preciso que uma realidade-humana supere o dado ao encontro do projecto da totalidade realizada - aqui o disco da lua cheia - e regresse de seguida ao encontro do dado para o constituir como crescente de lua. Ou seja, para o realizar no seu ser a partir da totalidade que devém o seu fundamento. ${ }^{10}$

Assim, tal como a lua cheia doa o sentido quer ao existente - os três quartos de lua -, quer ao carecido - o quarto de lua -, também o ser da consciência se constitui como o sentido da consciência existente como a totalidade de ser - o seu $\mathrm{Si}$ - que está para lá daquilo que é objecto para a consciência. Ora bem, esse ser que a consciência é, não o sendo, não surge diante da consciência como objecto, ou seja, ela não é consciência desse ser, uma vez que este só a marca como seu sentido de ser enquanto assombramento da consciência não-posicional de si. A carência que a consciência é tira desse ser o seu sentido último, é o cumprimento desse ser que ela procura realizar em cada acto intencional. Todas as condutas humanas estão inscritas neste projecto de supressão da falta ou carência ontológica, num projecto de ser que tem a síntese entre o Para-si e o $\mathrm{Si}$ como seu cumprimento.

Mas este ser que a consciência é através da sua negação interna, não o sendo, e que se dá à consciência como sentido do seu agir, que tipo de ser é o seu?

Para Sartre, o ser do Si é o valor:

Podemos presentemente determinar com mais clareza aquilo que é o ser do Si: é o valor. O valor, com efeito, está afectado dessa dupla característica, que os moralistas explicaram de forma muito incompleta, de ser incondicionalmente e de não ser. Enquanto valor, com efeito, o valor tem ser; mas esse existente normativo não tem precisamente ser enquanto realidade. ${ }^{11}$

O ser do Para-si é, para Sartre, superação, arrancamento ao ser na direcção, no sentido de um Si que não é objecto de conhecimento, que não aparece enquanto objecto diante da consciência, mas que é dado na espontaneidade ou translucidez não-posicional da consciência como assombramento vivido, como a sombra do fundamento do nada de ser que o Para-si é, como sentido da liberdade da consciência; em suma, como fundamento e sentido - simultaneamente presente e fora do alcance - da presença enquanto poder nadificante do que lhe está presente. O valor é a

10 E.N., pp. 122-123.

11 E.N., p. 129. 
totalidade de todas as carências, é aquilo que o Para-si tem a ser, na medida em que é o fundamento vivido pela consciência não-tética do nada de ser que ela é enquanto é Para-si, é o sentido concreto da carência de ser que constitui o Para-si.

Sartre afirma, assim, que o valor ou o $\mathrm{Si}$, apesar de ter ser, não tem realidade, ou seja, que não há, no seu ser, nenhum rasto de positividade. Ainda que isto possa ser verdade do ponto de vista do conhecimento, do valor sempre que é tomado como tema ou objecto da consciência, torna-se difícil perceber como é que, no que diz respeito à consciência não-tética, ele pode ser vivido de uma outra forma que não positivamente. Estender o âmbito da tese acerca do nada de ser que o Si é da consciência tética à consciência não-tética, é esquecer que o nada só pode advir ao ser vindo do ser, isto é, que, se o seu ser tematicamente tomado é nada, só o pode ser pela negação do ser que ele é em função de algo dado positivamente ao nível da consciência não-tética ${ }^{12}$.

Podemos inferir destas considerações que a identificação do ser da consciência com o seu aparecer, operada por Sartre, não é válida, pois a não-coincidência que caracteriza o ser do Para-si pode até não ter a consistência de uma coisa, mas tem alguma positividade de ser que não se esgota no seu aparecer.

No final deste processo apuramos que a inconsistência de ser que afecta no seu âmago o Para-si não assenta na não-conformidade entre o sujeito e o seu Si, mas está fundada na carência, falta ou desejo de ser, tal como Sartre a caracteriza, lida de uma forma mais radical: o Para-si não quer ser o Si que lhe falta enquanto totalidade sintética do Para-si com o em-si, mas antes dar consistência ao seu ser próprio, dotar-se de um ser seu. Expliquemo-nos melhor: a consciência caracteriza-se pela sua carência de ser, projectando a totalidade do seu ser para lá do ser que lhe está presente e, constituindo-a como sentido do seu ser; essa totalidade surge apenas como limite orientador do ser da consciência, isto é, a distância que falta colmatar para que a consciência possa realizar o seu projecto de ser, para que possa ser o fundamento do seu próprio ser, e não como o seu fundamento de facto.

Segundo Sartre, a totalidade ou Si resulta da síntese entre Para-si e em-si, totalidade impossível porque implicaria a coisificação do Para-si, tornando-o um em-si. Contudo, estas relações entre Para-si, em-si e Si esclarecem o tipo de ser dos dois últimos - aquilo que está presente e o sentido, respectivamente -, e nunca do Para-si, cujo ser, como vimos, não pode reduzir-se ao Nada que Sartre advoga e que afirma fundá-lo, mas antes a uma positividade que não foi ainda aferida e que permanece transcendente aos actos intencionais.

12 Tal como o negativo de uma fotografia só o pode ser em função da sua contraparte positiva e vice-versa. 
Podemos agora afirmar, contra Sartre, que o Si, enquanto totalidade, não é o fundamento da consciência, não é o seu ser de facto, mas apenas um sentido, uma mostra não-posicional, vivida, da direcção que o Para-si tem que tomar para se fundar, ou seja, para ter um ser seu. Ao caracterizar a consciência como falta ou carência de uma totalidade - Si - que permanece fora do seu alcance como valor, cujo ser se dá como sentido do arrancamento a si que caracteriza a consciência desejante, Sartre não vê que essa totalidade apenas mostra à consciência o sentido do seu ser como movimento em direcção à fundação do seu próprio ser, e não o seu fundamento ele mesmo.

Consequentemente, a consciência é uma criação ex-nihilo, uma espontaneidade surgida do nada que constitui o seu ser enquanto aquilo que aparece para lá do objecto tematicamente tomado, mas o sentido deste nada está ainda por apurar. O surgimento de uma realidade-humana ou Para-si é, ele mesmo, o resultado de um acto ontológico de separação do em-si que imediatamente coloca a questão do sentido do seu ser próprio, fazendo-o surgir como horizonte, como direcção a tomar para que o Para-si possa ser o que é, e não para que possa ser o que não é, ou seja, um em-si.

Assim, o surgimento, no horizonte do Para-si, de um ser que ele não é, mas devia ser - surgimento que envolve uma noção de sentido na sua dupla acepção de direcção e de vivência íntima, e não uma presença ao seu ser de facto - implica que a consciência visa, em todo o acto intencional, ser contemporânea do seu fundamento, implica que o ser da consciência é esse compromisso consigo mesma, saindo de si para fundar o seu ser, para estar na sua presença, embora este lhe permaneça transcendente.

Em jeito de conclusão intercalar, estamos em condições de declarar que é pela consciência que a questão do fundamento surge no mundo, pois só ela é capaz de constituir para si mesma um sentido, quer dela própria, quer das coisas que lhe estão presentes, mas isso não obriga a que a consciência seja o fundamento ontológico do seu Para-si. Posto noutros termos, a consciência é condição necessária para que a questão do fundamento, enquanto sentido do seu ser próprio, surja no mundo, mas isso não obriga a que a consciência seja esse fundamento ele mesmo, isto é, a que seja condição suficiente do seu Para-si.

Assim, a consciência não é uma pura imanência, pois o seu fundamento é-lhe transcendente, embora isto não implique a introdução de uma opacidade na consciência e a sua coisificação, porque ela permanece sendo espontaneidade, mas espontaneidade determinada, comprometida na direcção da constituição de si, projecto de libertação e liberdade possível, não liberdade de facto.

Resumindo, a determinação do ser da consciência como Para-si, isto é, como consciência tética de objecto e consciência não-tética de si, obri- 
ga a que cada tentativa de tematização do seu próprio ser esteja votada ao fracasso, porque esse ser se escapa, de cada vez, num poder nadificante que toma como objecto uma parte desse ser, e não o ser no seu todo. Assim, Sartre concebe esse ser como um nada.

No entanto, se cada tentativa de objectivação de si encontra no outro extremo um vazio, um nada que se escapa eternamente, isto não é porque o próprio ser da consciência não tenha qualquer positividade, mas porque a consciência está numa relação de transcendência relativamente a ele.

$\mathrm{O}$ ser do $\mathrm{Si}$, a que a consciência se refere e que resulta nesse poder nadificante, remete, por sua vez - e na exacta medida em que a consciência é um desejo que se direcciona para o desejado, mas que implica, ainda que não-teticamente, um desejante, aquele que carece de realização -, para um eu que é o fundamento desse desejo enquanto ser da consciência, um eu que não é um habitante feito coisa da consciência, mas que é transcendente a ela. Dito de outro modo, se o ser da consciência não coincide com o seu aparecer e se dá, assim, como transcendente ao seu agir no modo de um poder desestruturante e desintegrador, ou seja, escapa sempre às tentativas de tematização da consciência e permanece outro relativamente a esta, então um mesmo que funde a permanência da consciência na transitividade dos seus diversos estados, como seu pólo unificador, como um eu, tem que estar presente, desde logo, no plano não-tético, sem ser objecto para a consciência. É esta tese, exactamente no pólo oposto da posição sartriana, que queremos defender aqui, nomeadamente no que respeita ao facto de a consciência não poder ser explicada como Para-si o que já vimos, pois o seu ser não se esgota no seu aparecer e, logo, ela não é, em sentido estrito, presença a si - mas como Para-outrem sob a ilusão de ser Para-si, uma vez que o seu ser se dá sempre como outro relativamente ao seu agir imanente, como sentido desse mesmo agir.

Nós afirmamos que a consciência não é Para-si, que o seu ser próprio é ser si mesmo como um outro, e uma análise do modo como Sartre compreende a relação a outrem servirá de ensejo para, partindo dos limites da sua argumentação tal como sublinhados nos parágrafos anteriores, mostrarmos como ele falha a compreensão não só dessa relação fundamental, mas também do próprio ser da consciência.

A análise sartriana do ser-para-outrem começa com uma questão aparentemente simples: o que é que significa, para a consciência enquanto essa realidade-humana que tentámos caracterizar e cujas deficiências julgamos ter demonstrado no ponto anterior, afirmar que um determinado objecto da sua experiência é um ser humano? 
Para Sartre, esta questão simples, que inicia o processo de análise do tipo de ser que a consciência é para uma outra consciência, remete ou pode ser dividida em duas questões complementares:

- por um lado, aquela que se refere à existência indubitável de outrem;

- por outro lado, e no seu desenvolvimento, aquela que concerne à relação entre a consciência própria e a consciência outra, isto é, à relação com outrem.

No nosso mundo encontramos objectos a que atribuímos um estatuto especial: denominamos esses objectos de humanos, tal como a nós próprios. Essa atribuição de humanidade a um objecto, na medida em que se funda apenas e só no encontro de um objecto que aparenta algumas similaridades connosco, permanece conjectural.

No entanto, a relação da consciência a outrem apresenta um outro aspecto: o da probabilidade. Nesse modo de a perspectivar, consideramos mais ou menos provável que um determinado acontecimento do nosso mundo esteja relacionado com esse outrem-objecto que se dá à consciência. Isto significa que a existência de outrem não se cinge a uma hipótese fundada num processo lógico mental, mas que, sendo provável, está sujeita a prova e que, assim sendo, sugere uma captação fundamental e originária de outrem, captação essa que é a sua verdade e para a qual os diversos aspectos da presença de outrem à consciência remetem.

A relação a outrem que está na base da probabilidade que atribuímos à sua existência é uma relação com outrem-sujeito, e não com outrem-objecto. Mas comecemos por perceber o significado da relação a outrem-objecto. Diz-nos Sartre:

Eu estou num jardim público. Perto de mim, eis um relvado e, ao longo desse relvado, cadeiras. Um homem passa perto das cadeiras. Eu vejo esse homem, eu capto-o, ao mesmo tempo, como um objecto e como um homem. Que é que isso significa? Que quero eu dizer quando afirmo desse objecto que ele é um homem?

Se eu devesse pensar que ele não é nada mais que um boneco, eu aplicar-lhe-ia as categorias que me servem vulgarmente para agrupar as «coisas» espácio-temporais. Ou seja, eu captá-lo-ia como estando «ao lado» das cadeiras, a 2,20 m do relvado, como exercendo uma certa pressão sobre o solo, etc. A sua relação com os outros objectos seria do tipo puramente aditivo; isso significa que eu poderia fazê-lo desaparecer sem que as relações dos outros objectos entre si sejam modificáveis de forma notável. Numa palavra, nenhuma relação nova apareceria por ele entre essas coisas do meu universo: agrupadas e sintetizadas do meu lado em complexos instrumentais, elas desagregar-se-iam do seu em multiplicidades de relações de indiferença. Per- 
cebê-lo como homem, pelo contrário, é captar uma relação não aditiva da cadeira a ele, é registar uma organização sem distância das coisas do meu universo em torno desse objecto privilegiado. ${ }^{13}$

O significado da posição de um homem pela consciência é o surgimento de uma relação diferente relativamente à posição pela consciência de outros objectos do mundo, a doação à consciência de uma relação sem distância do homem às coisas do mundo, sendo este último a unidade de sentido da multiplicidade de objectos presentes à consciência, um obstáculo cuja superação conduz a consciência ao encontro de si mesma.

O que é que isto significa?

Significa que a consciência capta, ao captar um homem, uma organização espacial das coisas intramundanas que tem esse homem como ponto de convergência, ou seja, é uma espacialidade que se abre, não para a consciência, mas na direcção desse homem que a consciência visa entre as coisas do mundo.

Assim, a relação surgida à consciência pelo aparecimento de um homem entre os objectos do seu mundo tem uma dupla face: por um lado, é uma relação dada na sua totalidade e oferece-se à consciência como objecto de conhecimento; por outro lado, ela escapa à consciência, na medida em que esta não pode colocar-se como centro organizador das distâncias que nela se abrem. Como tal, essa relação

aparece como uma pura desintegração das relações que eu apreendo entre os objectos do meu universo. E essa desintegração, não sou eu que a realizo; ela aparece-me como uma relação que eu viso no vazio através das distâncias que eu estabeleço originalmente entre as coisas. É como um pano de fundo das coisas que me escapa por princípio e que lhes é conferido de fora. Assim, a aparição, entre os objectos do meu universo, de um elemento de desintegração desse universo, é aquilo a que eu chamo aparição de um homem no meu universo. Outrem é, desde logo, a fuga permanente das coisas ao encontro de um termo que eu capto, ao mesmo tempo, como objecto a uma certa distância de mim, e que me escapa na medida em que ele abre em seu torno as suas próprias distâncias. ${ }^{14}$

A desintegração ocorrida pela entrada de outrem, enquanto objecto, na existência da consciência tem como resultado um descentramento do mundo relativamente à consciência. Assim, visar um objecto-homem significa, para a consciência, que existe, entre os seus actos intencionais, um que tem a característica muito peculiar de não esgotar o seu sentido

13 E.N., p. 293.

14 E.N., p. 294. 
na significação projectada pela consciência, mas que permanece para lá dessa significação, que a excede e que, para além do mais, retira à consciência o seu lugar privilegiado na organização do mundo.

A percepção de um objecto-humano no mundo implica, para a consciência, o reconhecimento de uma relação entre as coisas surgidas nessa totalidade de significações semelhante à que ela própria estabelece com essas mesmas coisas. Ao surgir como termo dessa relação, conferindo aos objectos um sentido, uma direcção que escapa à consciência, o homem surgido no campo perceptivo torna-se o centro de um mundo que, a um tempo, é o da consciência e já não o é mais, aparecendo como uma descentração, como uma negação das distâncias, das relações visadas pela consciência entre os objectos do seu universo.

Para Sartre, a aparição de outrem no mundo provoca uma abertura desse mesmo mundo num sentido que escapa à consciência; a totalidade de significações ou mundo que é operada pela acção da consciência, pelo seu poder nadificante que lhe permite ter a sua existência como objecto, como obstáculo ou como problema, sofre uma ruptura pela entrada em cena de outrem, uma ruptura que não apenas retira ao mundo o seu carácter de totalidade, como mostra à consciência que há sentidos da sua existência que lhe escapam.

Na verdade, no nosso ponto de vista, Sartre não vai, neste ponto, suficientemente longe na análise, devido à sua posição acerca do ser da consciência, posição que discutimos em linhas anteriores. Efectivamente, a descrição que Sartre aqui faz da entrada de outrem no mundo enquanto objecto e da fractura destotalizante correspondente está desde sempre e já presente à consciência nas restantes operações quotidianas, como aquilo a que ele chama nada, pois é o sentido do seu ser que lhe escapa desde logo, como vimos atrás. Retornaremos a este assunto mais adiante.

Assim, outrem é definido, para a consciência, como uma ausência no seio do mundo. No entanto, a ausência que define outrem não o define a partir de si mesmo, pois ele está presente à consciência como objecto, mas a partir do próprio mundo, como aquilo a partir do qual outrem se deixa compreender enquanto uma totalidade de significações que, surgida no interior da totalidade operada pela consciência, a desintegra, tornando a experiência de outrem-objecto na irrupção de uma carência de mundo no âmago do próprio mundo da consciência. De acordo com Sartre,

[...] outrem define-se, não como ausência de uma consciência em relação ao corpo que eu vejo, mas pela ausência do mundo que eu percebo no seio mesmo da minha percepção desse mundo. Outrem é, nesse plano, um objecto do mundo que se deixa definir pelo mundo. Mas essa relação de fuga e de ausência do mundo em relação a mim não é senão provável. Se é ela que define a objectividade de outrem, a que presença 
original de outrem ela se refere? Podemos responder presentemente: se outrem-objecto se define em ligação com o mundo como o objecto que vê aquilo que eu vejo, a minha ligação fundamental com outrem-sujeito deve poder reconduzir-se à minha possibilidade permanente de ser visto por outrem. É na e pela revelação do meu ser-objecto para outrem que eu devo poder captar a presença do seu ser-sujeito. ${ }^{15}$

E é aqui que o projecto sartriano de análise do sentido da alteridade para a consciência se define e, simultaneamente, limita o seu alcance. Vejamos:

- se, por um lado, podemos até concordar que a objectividade de outrem nos deixa, relativamente à afirmação da sua existência que a acompanha, no campo da probabilidade, remetendo-nos para uma relação originária a outrem enquanto presença e, portanto, enquanto sujeito que nos vê;

- por outro lado, não podemos concordar com a leitura que Sartre avança desse ver. Conquanto admitamos que outrem-sujeito possa ver a consciência, o que ele visa aí, de uma forma peculiar que Sartre não concebe, é a consciência enquanto sujeito que ela nunca cessa de ser.

Essa é a diferença fundamental entre o Para-si e o Para-outrem, que resulta de uma inferência imediata que Sartre não tirou - ou não quis tirar - das suas próprias exigências conceptuais: enquanto o Para-si - com cuja concepção não concordamos - tem apenas a outra consciência como objecto, outrem visa-o naquilo que ele é, no seu ser, sem que esta identidade - que, aliás, é pressuposta por Sartre sob o modo, quanto a nós errado, da coincidência entre ser e aparecer, não invalidando, para Sartre, a estrutura subjectiva do Para-si - signifique a cristalização da consciência num em-si, mas antes a realização do projecto da própria consciência, o seu ser sujeito e, portanto, Para-si (para continuarmos a utilizar a terminologia sartriana). Na nossa perspectiva, outrem mostra à consciência o ser que ela devia ser e não é. Contudo, isto não ocorre através da sua coisificação, da sua redução a objecto do mundo, mas antes através da sua subjectivação efectiva, pois ser-sujeito é o ser próprio da consciência.

Conquanto não concordemos com a leitura sartriana do olhar de outrem, isto não significa que devamos descartar toda a sua análise fenomenológica. A pretensão do texto que aqui apresentamos é mostrar alguns dos seus limites e apontar o caminho para uma outra leitura possível dos mesmos dados. Como tal, prosseguiremos com uma leitura crítica da análise fenomenológica efectuada por Sartre relativamente ao olhar.

15 E.N., p. 296. 
Colocando a questão do sentido do olhar de outrem, diz Sartre:

Aquilo a que se refere a minha apreensão de outrem no mundo como sendo provavelmente um homem é à minha possibilidade permanente de ser-visto-por-ele, isto é, à possibilidade permanente para um sujeito que me vê de se substituir ao objecto visto por mim. ${ }^{16}$

E, muito subtilmente, foi introduzida uma identidade ou uma intersubstituibilidade de expressões que estão muito longe de significar o mesmo: dizer que visar um homem se refere à possibilidade permanente da consciência de ser vista por outrem não é o mesmo que dizer que essa mesma percepção se refere a uma possibilidade desse sujeito que vê a consciência de se substituir ao objecto que esta vê; a possibilidade de ser-vista permanece sendo $d a$ consciência, e não de outrem, e são estas subtilezas e flutuações na argumentação que conduzirão Sartre a uma concepção da relação entre consciências como conflito.

Sartre esboça do seguinte modo as condições e a finalidade de uma análise do olhar de outrem:

A relação original de mim mesmo a outrem não é somente uma verdade ausente visada através da presença concreta de um objecto no meu universo; ela é também uma relação concreta e quotidiana da qual eu faço, a cada instante, a experiência: a cada instante outrem olha-me; é-nos, assim, fácil tentar, com exemplos concretos, a descrição dessa ligação fundamental que deve fazer a base de toda a teoria de outrem; se outrem é, por princípio, aquele que me olha, nós devemos poder explicitar o sentido do olhar de outrem. ${ }^{17}$

A verdade da percepção de outrem através do seu olhar não é a captação da sua materialidade, não é a percepção de uns olhos postos aí diante da consciência e cuja presentificação esgota o seu sentido, pois captar uma outra consciência tendo como intermediário o mundo, ou seja, tendo-a sempre como objecto do mundo, implica o desvanecimento da percepção, uma retirada de outrem da esfera do próprio, da esfera da consciência ou, como Sartre lhe chama sem alcançar o seu significado mais fundo, da esfera do Para-si.

A verdade da percepção de outrem é um sentimento imediato da sua presença e, portanto, o sentimento da sua subjectividade, e não a sua redução a um objecto provável.

16 E.N., p. 296

17 E.N., pp. 296-297. 
Sartre escolhe como exemplo para esta hermenêutica da experiência da alteridade uma situação que envolve um comportamento ciumento ou interessado. Por outras palavras, Sartre escolhe como exemplo uma situação que implica uma certa desconfiança da consciência relativamente ao que lhe está presente; esta desconfiança, enquanto atitude hermenêutica, implica que a consciência, ao mesmo tempo que toma interesse por determinados acontecimentos, ou seja, enquanto tem como objecto intencional e, portanto, significativo, uma dada relação entre coisas do seu mundo, se coloca de fora desse agregado concatenado pela sua acção significativa, enquanto presença a uma dada situação. Resumindo: o ponto de partida de Sartre é o Para-si, a consciência irreflectida.

Para Sartre, a consciência encontra-se, nessa situação, sob o plano da consciência não-tética de si, plano de que falámos em páginas anteriores e no qual não existe um eu que a habite; logo, aquilo a que a consciência se reporta para qualificar os seus actos é a si mesma enquanto poder nadificante, a um nada e, logo, as suas acções estão situadas num plano horizontal, sem uma qualificação exterior a elas que possa conferir-lhes alguma espessura, alguma estratificação. Diz Sartre:

Nada, consequentemente, a que eu possa reportar os meus actos para os qualificar. Eles não são conhecidos, mas eu sou-os e, desse facto apenas eles retiram a sua total justificação. Eu sou pura consciência das coisas e as coisas, tomadas no circuito da minha ipseidade, oferecem-me as suas potencialidades como réplica da minha consciência não-tética (das) minhas possibilidades próprias.

E prossegue, concluindo:

Nenhuma vista transcendente vem conferir aos meus actos um carácter de dado sobre o qual possa exercer-se um juízo: a minha consciência cola-se aos meus actos; ela é os meus actos; eles são somente comandados pelos fins a atingir e pelos instrumentos a empregar. ${ }^{18}$

Já vimos como esta identidade entre a consciência e os seus actos é problemática. Se quisermos ser precisos, Sartre teria aqui de se reportar à consciência, no circuito de ipseidade e, portanto, na esfera daquilo que lhe é reenviado pelo mundo ao qual ela é presença, mas ao qual não é idêntica, como tendo esses actos, não como sendo os mesmo, pois o que caracteriza a esfera do próprio da consciência, enquanto abstracção e ainda que enquanto consciência não-tética de si ou consciência irreflectida, é o facto de esta se colocar diante das acções como diante da sua propriedade, não se esgotando nelas e, consequentemente, não sendo idêntica

18 E.N., p. 298. 
a elas - há uma relação com as acções, mas as acções não esgotam o ser da consciência, como bem vimos acima, pois esta projecta-se, no momento da sua realização efectiva, para lá delas, negando a identidade e qualquer tipo de reciprocidade na relação de pertença.

O próprio Sartre reconhece, embora de forma ambígua, esta não identidade entre a consciência e as acções possíveis reenviadas pela facticidade ou contingência - que a consciência não é, mas que permanece como um peso à distância que carrega consigo e a partir do qual se faz presença -, e pela liberdade enquanto projecção problemática de possibilidades de sentido do ser da consciência - cuja efectividade é a verdadeira finalidade da acção intencional particular, que não é um fim em si mesma - para lá da consciência presente:

Assim, não somente eu não posso conhecer-me, mas o meu ser mesmo escapa-me, embora eu seja esse escape mesmo ao meu ser, e eu não sou nada, de facto; não há nada aí senão um puro nada rodeando e fazendo sobressair um certo conjunto objectivo recortando-se no mundo, um sistema real, um agenciamento de meios em vista de um fim. ${ }^{19}$

Quais são, então, para Sartre, as modificações introduzidas na consciência pelo olhar de outrem, tendo em conta que este olhar não se refere à captação de um objecto-olhar pela consciência, mas a uma consciência de ser olhado que se adianta, ou que se antecipa, à presentificação dos olhos de outrem?

Segundo Sartre, o olhar de outrem faz irromper na consciência irreflectida - que não é objecto para si mesma - um eu que não estava lá antes, enquanto considerada na sua solidão existencial, enquanto Para-si. $\mathrm{O} e u$ torna-se presente à consciência não enquanto é objecto para ela, mas enquanto é objecto para outrem, e isso

significa que tenho de um só golpe consciência de mim na medida em que me escapo, não na medida em que sou o fundamento do meu próprio nada, mas na medida em que tenho o meu fundamento fora de mim. Eu não sou para mim senão como puro reenvio a outrem. ${ }^{20}$

No entanto, outrem não é aqui um objecto que tem como significação associada o ego presente à consciência. $\mathrm{O}$ que caracteriza a experiência de outrem é o facto de este não se tornar objecto para a consciência sem que, simultaneamente, o eu deixe de ser objecto para outrem e, assim, deixe de estar presente à consciência não-tética. A consciência visa

19 E.N., p. 299.

20 E.N., p. 300. 
esse ego de súbito presente atematicamente na medida em que ele não é para ela, na medida em que ele está separado dela por um nada que ela não pode preencher, como faria se quer outrem, quer esse ego fossem dados tematicamente para si. O ego é visado pela consciência como algo que permanecerá sempre fora do seu alcance, como algo que escapa ao seu âmbito por princípio.

Contudo, a relação que a consciência estabelece com o seu eu, surgido pela entrada em cena de outrem-sujeito - que é o intermediário dessa relação - não é uma relação de estranheza, de recusa, mas de aceitação, de reconhecimento de si nesse eu que se dá como uma dimensão do seu ser que se furta à sua visada objectivante e que necessita de outrem para que a possa reconquistar, como um eu que ela é, ainda que não o tenha como objecto de conhecimento.

Este sentimento de afinidade, de identidade com um eu que não pode ser conhecido por si e que se faz presente através da experiência da alteridade, é dado à consciência por uma vivência particular: a vergonha.

O que é, então, a vergonha? Que estrutura particular possui esta vivência para que se destaque da outras, trazendo uma nova dimensão ontológica, uma dimensão ontológica que é da consciência sem ser para ela?

A vergonha tem uma estrutura ontológica para outrem, isto é, é uma estrutura do ser da consciência, mas sem que esse ser seja para ela. A consciência de vergonha é, tal como todos os outros actos intencionais, uma vivência acessível à reflexão, pois a sua estrutura é intencional e, como tal, é apreensão vergonhosa que a consciência tem de si mesma do ponto de vista reflexivo, ou seja, tendo o seu acto intencional como objecto.

No entanto, não é como fenómeno da reflexão que a vergonha surge originalmente. A estrutura original da vergonha implica sempre um outro, esse diante do qual a consciência é vergonha e que serve de mediador dessa relação, uma relação íntima, interior e afectiva que a consciência estabelece consigo mesma.

De acordo com Sartre, a aparição de outrem torna possível à consciência realizar um juízo sobre si mesma tal como o faria se estivesse aí em jogo um objecto, uma vez que é como objecto que aparece a outrem. Assim, a vergonha é reconhecimento de que a consciência é tal como é vista por outrem, por essa outra consciência entretanto surgida e que provoca um estremecimento, uma afecção não antecipada no interior da actividade da consciência que lhe mostra, através do sentimento da sua vulgaridade, o carácter público das suas acções.

Em suma, a vergonha mostra que a consciência não está só, que existem outros e que, como tal, há uma dimensão nova do seu ser que está sujeita a juízos de valor e da qual ela é responsável.

Assim, a vergonha é uma vivência, uma Erlebnis que revela um modo da consciência diferente da consciência reflectida ou tomada como 
objecto de reflexão, e da consciência irreflectida que não se distingue do acto de apreender o mundo enquanto totalidade de significações. A vergonha, para Sartre, não está relacionada a algo merecedor de censura, mas antes a uma alienação que a consciência sofre pelo facto de o seu ser lhe escapar e, assim, carecer de outrem para o reconquistar. Por essa razão, Sartre afirma:

Eu não posso ter vergonha senão da minha liberdade na medida em que ela me escapa para devir objecto dado. Assim, originalmente, o elo da minha consciência irreflectida ao meu ego-olhado é um elo não de conhecer, mas de ser. Eu sou, para lá de todo o conhecimento que eu possa ter, esse eu (moi) que um outro conhece. E esse eu (moi) que eu sou, eu sou-o num mundo que outrem me alienou, pois o olhar de outrem envolve o meu ser e, correlativamente, as paredes, a porta, a fechadura. $^{21}$

A relação da consciência com o ser que a vergonha lhe revelou é uma relação de ser. Isto significa que a consciência é o ser revelado por outrem, um ser que é, para ela, indeterminado, precisamente porque não depende da sua liberdade, da sua capacidade de o colocar diante de si e o pôr em questão, mas da liberdade de outrem, na medida em que esta se revela através da indeterminação do ser que a consciência é para essa outra subjectividade. De acordo com Sartre, esse ser é o limite da liberdade da consciência, uma sombra que sobre ela se projecta, um espaço privado de luz, não por interposição de um corpo opaco bem circunscrito na sua luminosidade, mas antes um espectro que assombra esse elemento indefinido que a consciência se revelou ser por intermédio de outrem e da vergonha. Diz-nos Sartre:

Trata-se do meu ser tal como ele se escreve na e pela liberdade de outrem. Tudo se passa como se eu tivesse uma dimensão de ser da qual eu estaria separado por um nada radical: e esse nada, é a liberdade de outrem; outrem tem a fazer ser o meu ser-para-ele na medida em que tem a ser o seu ser. ${ }^{22}$

Esta passagem é algo problemática, uma vez que reconhece a existência de dois nadas, aquele que diz respeito ao poder nadificante do Para-si relativamente aos objectos a que é presença, e agora este, relativo a outrem. Com isto queremos chamar a atenção para o facto de Sartre ignorar o facto de o nada que remete para a liberdade de outrem poder - e mesmo dever, pois são inconcebíveis dois conjuntos vazios distintos entre

21 E.N., p. 300.

22 E.N., p. 301. 
si - ser precisamente o mesmo nada que se revela tematicamente como totalidade de que o Para-si, enquanto carência ou desejo, carece para se realizar. Deste modo, teríamos a liberdade de outrem como criadora do ser da consciência, e estaria explicada a criação ex-nihilo da consciência, essa espontaneidade nascida de um nada que não é mais do que a liberdade de outrem enquanto constitutiva do ser da consciência.

Por outras palavras, concebida dessa forma, a consciência passaria a ser não um Para-si que questiona o seu ser, mas originalmente uma resposta a outrem que, esse sim, põe o ser da consciência em questão, o que não invalida o facto de a consciência ser livre para decidir acerca do seu ser, pois apenas lhe fornece uma orientação.

No entanto, esta posição conduziria a um abandono da concepção sartriana da consciência como Para-si - que, como vimos, não está isenta de problemas - e à sua concepção como Para-outrem, uma vez que o que a caracterizaria não seria já o facto de originariamente se fundar a si mesma e, desde logo, cuidar do seu ser, através do questionamento, mas antes, e mais primitivamente, o ter o seu fundamento fora de si, num outro, e, por intermédio do cuidar do seu ser, intentar relacionar-se, ainda que ontologicamente - mas não eticamente - condenada ao insucesso, com o seu fundamento mediante a relação com outrem. Assim, outrem surgiria não como obstáculo, mas como o sentido do ser da consciência.

Esta posição subordinaria a ontologia à ética e é sustentada não só pelas deficiências da concepção sartriana de consciência, mas também por uma análise menos estreita da vergonha enquanto acto de consciência. Se a vergonha é alienação de ser para a consciência, ela é-o de um ponto de vista negativo, na leitura de Sartre.

Contudo, há uma contrapartida positiva desta alienação, precisamente aquela que assinalámos: se a consciência carece de outrem para que possa captar todas as estruturas do seu ser, ou seja, para recuperar essa dimensão que outrem lhe confere e que lhe escapa, se só outrem pode revelar a consciência a si mesma, não enquanto poder nadificante, mas no seu ser ele mesmo, então é porque outrem detém a solução daquilo que a consciência é e, desse modo, conserva o segredo do seu ser.

Pela vergonha, a consciência reconhece como seu esse ser que outrem lhe atribui e, portanto, reivindica como sua a liberdade de um outro, pois reconhece, a um tempo:

- por um lado, que o seu ser é tal como outrem o concebe;

- por outro, aceitando essa concepção como de uma outra consciência, reconhece-se na liberdade dessa outra consciência, reivindicando-a para si e reconhecendo o seu ser como essa liberdade mesma.

Diz Sartre: 
Pela minha vergonha mesma, eu reivindico como minha essa liberdade de um outro, eu afirmo uma unidade profunda das consciências, não essa harmonia das mónadas que tomámos por vezes como garantia de objectividade, mas uma unidade de ser, já que eu aceito e eu quero que os outros me confiram um ser que eu reconheço. ${ }^{23}$

A entrada em cena de outrem e o reconhecimento da sua liberdade pela consciência tem como efeito o desnudamento da consciência, e é esse acontecimento que Sartre apresenta aqui condensado como vergonha.

De facto, na solidão do Para-si, a consciência revestia-se das suas diversas modalidades existenciais, mostrando-se nelas, mas simultaneamente diferenciando-se e fazendo-se testemunho desse seu ser que se dava sempre numa transcendência que a consciência se fazia não ser por intermédio de uma negação interna que a induzia a questionar se esse ser transcendente seria efectivamente o seu e não uma simples máscara. Agora, com a experiência da alteridade, a máscara que revestia o ser da consciência cai e o seu ser, embora permanecendo transcendente para a consciência, adquire uma figura, tem uma natureza que lhe pode ser atribuída e da qual a consciência não se pode evadir, ainda que o conhecimento dessa natureza lhe esteja vedado e, por isso mesmo, ela lhe escape. Por isso, como diz Sartre, o outro, enquanto olhar, é a transcendência transcendida da consciência, ou seja:

Eu sou sempre, sem dúvida, as minhas possibilidades, sob o modo de consciência não-tética (de) essas possibilidades; mas, ao mesmo tempo, o olhar aliena-mas: até aí, eu captava teticamente essas possibilidades sobre o mundo e no mundo, a título de potencialidade dos utensílios; [...] essa qualidade ou utensilidade do objecto não pertencia senão a ele somente e dava-se como uma propriedade objectiva e ideal, marcando a sua pertença real a esse complexo a que chamámos situação. Mas, como o olhar de outrem, uma organização nova dos complexos vem sobre-imprimir-se sobre a primeira. Captar-me como visto, com efeito, é captar-me como visto no mundo e a partir do mundo. ${ }^{24}$

O olhar de outrem aliena não apenas as possibilidades da consciência mas, enquanto capta as relações desta com os objectos do mundo e a partir do mundo, aliena-lhe também o mundo, pois já não é um mundo para ela, mas para outrem, que o organiza e estabelece um limite às possibilidades da consciência.

23 E.N., p. 301

24 E.N., p. 302. 
Esse estranhamento ou alienação que o olhar de outrem provoca vai ao encontro da consciência imersa numa situação, congelando a sua relação de doação de finalidade aos objectos e surpreendendo-a justamente nesse conjunto de relações concatenadas, que recebem uma orientação diversa daquela que a consciência lhe doava e que, segundo a tese de Sartre, ia no sentido do pleno cumprimento do seu ser.

Por outras palavras, só há mundo, para Sartre, na medida em que esse mundo reenvia a um nada - a consciência - e que este nada procura superar esse mundo como obstáculo ao seu ser possível, o ser em-si. Agora, esse mundo tem uma orientação nova, ou seja, surge como totalidade de significações que reenviam a um outro, enquanto ele se faz ser e encontra a consciência própria no seio desse mundo, enquanto totalidade de relações de reenvio que, também elas, são um obstáculo à realização do seu ser. Assim, a consciência adquire um ser, ela é algo não apenas possível, mas de facto, ou seja, ela é alguém no meio de um mundo cuja orientação lhe escapa. E é justamente porque essa orientação lhe permanece desconhecida que, por um lado, o sentido do ser que ela é para outrem se esconde e, por outro ou como consequência -, que cada um dos seus actos, cujo horizonte ou plenitude de ser se desconhece e depende de outrem, pode servir a outrem para a atingir no seu ser, pois são apenas obstáculos à efectivação do seu ser próprio. Por essa razão, Sartre afirma o seguinte:

Dito de outro modo, todo o acto feito contra outrem pode, por princípio, ser para outrem um instrumento que lhe servirá contra mim. E eu capto precisamente outrem, não na clara visão do que ele pode fazer com o meu acto, mas num medo que vive todas as minhas possibilidades como ambivalentes. Outrem é a morte escondida das minhas possibilidades, na medida em que eu viso essa morte como escondida no meio do mundo. ${ }^{25}$

Sartre refere, nesta passagem, o carácter ambivalente das possibilidades da consciência, na medida em que reconhece o seu ser para outrem. O que deveria ter referido, também, é que as suas teses pendem sistematicamente para um dos termos dessa ambivalência, descurando o outro, o que é apoiado pelo próprio sentido da palavra ambivalência.

Senão vejamos:

- inserida no mundo, a ambivalência refere-se a um estado de coisas cujas possibilidades de desenvolvimento são incertas e que, por esse motivo, caracterizam uma situação de encruzilhada;

- vivida do ponto de vista do Para-si, a ambivalência traduz uma certa indecisão ou incerteza no que diz respeito ao caminho a seguir,

25 E.N., p. 304. 
às escolhas a fazer, manifestando-se, em dado momento, sob a capa do medo do desconhecido, da ameaça velada.

No que é que isto se relaciona com o que aqui está em questão?

No seguinte: ainda que haja alguma verdade na descrição sartriana, quer no caso aqui em presença, quer nos diversos momentos em que se trata da questão da alteridade, e que esse estranhamento de si, essa estratificação e alienação de si numa solidificação brusca de ser da consciência-olhada ocorra de facto e esteja aí, acessível à análise de todos, não é menos verdade que é esse o momento que Sartre elege e que enfatiza, esquecendo que a humilhação sofrida pela vergonha não é a verdadeira anomalia. A verdadeira anomalia consiste na doação de supremacia a este tipo de experiência sobre tudo o resto, conferindo-lhe um carácter obsessivo. Quando se refere aqui ao medo, à angústia sofrida pela consciência, pela realidade-humana devido ao facto de cada um dos seus actos intencionais, de realização de si, comportar uma dimensão desconhecida e possivelmente letal, Sartre esquece que a alternativa à acção é, justamente, a indecisão e a recusa pela consciência do seu ser tal como ele é, o que mergulha a consciência, enquanto actividade, no não-ser.

Se quisermos relacionar esta questão com a própria concepção de consciência avançada por Sartre, como Para-si, percebemos que este último, na medida em que é os seus possíveis não os sendo, configura precisamente este momento de indecisão, de dúvida perpétua relativamente ao seu ser. Esta suspensão serve bem para começar a análise referente ao ser da consciência, enquanto perspectiva abstracta momentânea, mas não serve para dar conta desse ser, pois, quando a encontramos para a analisar, a consciência está já concretamente ocupada do seu ser e, portanto, já se decidiu por ele, num tempo prévio à análise ${ }^{26}$.

Outrem, para se fazer ser, supera a situação em que encontra a consciência, solidificando-a e organizando-a numa forma, na qual a percepção ou olhar que caracteriza a consciência é tomado, por outrem, como uma relação do objecto $e u$ - da consciência, bem entendido - com os objectos percebidos, constituindo a consciência num todo organizado com finalidade interna que se pode dispor a si mesma numa relação meio-fim para realizar a sua presença à distância a um outro objecto. Tudo permanece semelhante para a consciência, com a excepção fundamental de a distância que se abre entre a consciência e o objecto ao qual ela se faz presença estar já dada, ou seja, ao captar o olhar de outrem, a consciência reconhece-se como espacializante-espacializado, como aquele que, fazendo vir

26 Veja-se, por exemplo, E.N., pp. 298-299, já na análise do olhar, como Sartre descreve hermeneuticamente o ciúme para surpreender esta indecisão ou suspensão sob a capa do ser da consciência. 
um lugar aos objectos, distribuindo-os de acordo com os seus fins, é dotado agora, também ele, de uma espacialidade, escapando-lhe o fim a que se destina; também a consciência ocupa um lugar.

A espacialidade conferida à consciência enquanto ser-olhado configura uma captação de si enquanto alvo de apreciações de valor, ou seja, enquanto objecto de um juízo ou de uma avaliação de um ser livre, cuja validade é reconhecida pela vergonha. Assim, para Sartre, a consciência ou a realidade-humana é constituída, pelo olhar de outrem, como um ser indefeso, ao dispor de uma liberdade alheia, mero instrumento de possibilidades que não são as suas e reduzida a ferramenta utilizável para fins que ignora, permanentemente em perigo, e é justamente esse perigo que constitui o seu ser-para-outrem:

Pelo olhar de outrem, eu viso-me como petrificado no meio do mundo, como em perigo, como irremediável. Mas eu não sei nem que sou eu, nem qual é o meu lugar no mundo, nem que face vira para outrem esse mundo em que eu sou. ${ }^{27}$

$\mathrm{Na}$ recta final deste comentário crítico resta-nos, partindo desta perigosidade representativa do ser-para-outrem, analisar as conclusões de Sartre acerca dessa mesma estrutura da consciência. Será essencial ainda efectuar algumas achegas para uma resolução possível da conflitualidade dialéctica a que Sartre vai chegar. Embora a análise do ser-para-outrem se estenda, em E.N., por muitas mais páginas, com diferentes abordagens e inúmeras ramificações, julgamos que a amostra aqui deixada será suficiente para ilustrar os limites das teses sartrianas, cujas dificuldades não residem tanto na diversidade, acuidade e âmbito da análise, quanto na metodologia adoptada, cuja repetição ao longo de toda a obra induz a uma perspectivação muito circunscrita quer do problema, quer posteriormente nas conclusões decorrentes da problematização.

Vimos, então, como o facto de outrem é incontestável, como a sua existência é indubitável, pois atinge a consciência no seu seio, ao nível da afectividade, pela vergonha, angústia ou mal-estar decorrentes da sua presença subjectiva, presença essa que é condição do ser da consciência, pois é dela que ele depende. Outrem é, para Sartre, uma perigosidade latente que é reenviada à consciência, na medida que é presença ao mundo enquanto totalidade de significações possíveis do seu ser, mas possibilidades que, sendo suas, são apenas pressentidas e reconhecidas através das afecções referidas, pois são constituídas por outrem, enquanto se faz ser.

27 E.N., p. 307. 
O que a análise da vergonha nos mostrou foi que outrem não é objecto da vergonha, nem esta depende de um encontro de outrem-objecto no mundo, podendo, se assim fosse, instalar-se a dúvida acerca da existência efectiva do olhar de outrem, ou então surgir a tese de se tratar apenas de uma crença infundada da consciência. A vergonha, esse pressentimento interno à consciência, não revela outrem à consciência como um objecto, mas como um outro sujeito, um outro momento da consciência que serve de motivação à consciência presente e é, nessa medida, no interior da própria consciência que outrem deve ser procurado. Outrem é um facto incontestável. Para Sartre:

Aquilo que é certo é que eu sou olhado, o que é somente provável é que o olhar esteja ligado a tal ou tal presença intramundana. Aliás, isso não tem nada que nos surpreenda, pois, já o vimos, não são nunca os olhos que nos olham: é outrem como sujeito. [...] O que é que, então, apareceu de forma enganadora [...]? Não é outrem-sujeito, nem a sua presença a mim: é a facticidade de outrem, isto é, a ligação contingente de outrem a um ser-objecto no meu mundo. Assim, o que é duvidoso, não é outrem ele mesmo, é o ser-aí de outrem. ${ }^{28}$

Ou seja, o que é duvidoso é a atribuição, pela consciência, de humanidade a um objecto do mundo, não a presença de outrem-sujeito no seio da própria consciência, o que conduz Sartre a uma análise da ausência como modo fundamental de doação de outrem por intermédio do mundo.

Para Sartre, a ausência é um modo de ser da realidade-humana em relação aos lugares e locais que ela determinou pela sua presença. Como tal, a ausência é uma relação entre realidades-humanas, ou seja, entre consciências, pois é como presença ao mundo que uma consciência, por um lado, visa outra consciência ou outrem e, por outro, a reconhece como já não estando aí, presente nesse objecto do mundo.

Como tal, esse reconhecimento assenta sobre uma presença fundamental das realidades-humanas umas às outras, isto é, a ausência é apenas um modo particular dessa presença. Por outras palavras, a ausência remete para um espaço humano de encontro, a consciência presente, ao visar um humano enquanto objecto do mundo e na exacta medida em que essa visada lhe permanece possível, remete para um passado em que ambas as consciências estariam presentes uma à outra, descobrindo-se mutuamente num encontro de olhares. A consciência situa-se sempre e já num espaço humano, refere-se sempre a ele na sua actividade, ou seja, é desde logo, na sua diferenciação particular, uma realidade-humana que encontra a sua humanidade como situação, como isso a partir do qual se faz ser. Contudo, no

28 E.N., pp. $316-317$. 
ponto de vista sartriano, o encontro de olhares, acontecimento concreto fundante da humanidade da consciência, tem um carácter meramente provável, uma vez que essa presença original não pode ter sentido senão como ser-percebido ou ser-olhado, e ser-olhante ou percipiente, isto é:

Numa palavra, é em relação a todo o homem vivo que toda a realidade-humana está presente ou ausente sob fundo da sua presença original. E essa presença original não pode ter sentido senão como ser-olhado ou como ser-olhante, ou seja, ou outrem é para mim objecto ou eu mesmo objecto para outrem. ${ }^{29}$

E essa é mesmo a natureza do olhar, isto é, todo o olhar remete para a aparição de outrem-objecto como presença concreta no campo perceptivo da consciência, e cujas atitudes conduzem a consciência a captar-se como ser-olhado, como vergonha, como angústia, em suma, como em perigo. E prossegue Sartre:

Esse «ser-olhado» apresenta-se como a pura probabilidade de que eu seja presentemente este aqui concreto - probabilidade que não pode tirar o seu sentido e a sua natureza mesma de provável senão de uma certeza fundamental que outrem me está sempre presente na medida em que sou sempre para outrem. A prova da minha condição de homem, objecto para todos os outros homens vivos, lançado na arena sob milhões de olhares e escapando-me a mim mesmo milhões de vezes, eu realizo-a concretamente na ocasião do surgimento de um objecto no meu universo, se esse objecto me indica que eu sou provavelmente objecto presentemente a título de este aqui diferenciado para uma consciência. É o conjunto do fenómeno a que chamamos olhar. ${ }^{30}$

Assim, a consciência existe para outras consciências, o olhar revela a existência indubitável desse outrem para o qual somos, muito embora ele não se revele objectivamente senão como provável. Para Sartre, o olhar permanece um olhar anónimo, um assombramento que assalta a consciência sem que possa ser atribuído, com toda a certeza, a um objecto do mundo.

Assim sendo, que tipo de relação pode a consciência ter com o seu outro, na medida em que é a presença deste que a constitui enquanto ego concatenador dos seus diversos estados e, logo, que lhe concede um ser próprio?

No que diz respeito a Sartre, a existência de um outrem em geral só acontece porque a consciência se faz ser, por intermédio da negação in-

29 E.N., p. 319.

30 E.N., p. 320. 
terna que a caracteriza, aquela que não é a outra, e esta negação interna é uma relação, um vínculo unitário de ser. Como tal, o outro existe para a consciência apenas como um si mesmo recusado, como uma totalidade de ser negada pela consciência. Diz-nos Sartre:

Aquele que eu me faço não ser, com efeito, não é somente enquanto eu o nego de mim que ele não é eu, mas eu faço-me precisamente não ser um ser que se faz não ser eu. Só que essa dupla negação é, num sentido, destruidora dela mesma: ou bem, com efeito, eu me faço não ser um certo ser e então ele é objecto para mim e eu perco a minha objectidade para ele; nesse caso o outro cessa de ser o outro-eu, isto é, o sujeito que se faz ser por recusa de ser eu; ou bem esse ser é o outro e se faz não ser eu, mas nesse caso eu devenho objecto para ele; e ele perde a sua objectidade própria. ${ }^{31}$

A disjunção que marca esta posição de Sartre é decisiva, pois é nesta dialéctica de conflito de liberdades e fugas à objectivação que ele concebe a relação entre consciências: ou a consciência é objecto para a outra, ou esta é objecto para a primeira. Mas este ponto de vista reside numa concepção muito estreita de consciência, de liberdade e da própria alteridade, pois faz permanecer a perspectiva da consciência enquanto Para-si e de outrem como outro Para-si e não enquanto outrem ele mesmo.

Como vimos, Sartre considera que o que marca o ser-para-outrem da consciência é o facto de reconhecer o seu ser-objecto e de se sentir ameaçada pela presença de uma outra consciência.

Mas esse é apenas um modo de ver as coisas.

De facto, se começarmos por olhar para a presença de outrem não como ameaçadora, ou como uma limitação da consciência e da sua liberdade, mas como gratuitidade, como doação e como entrega, talvez comecemos a compreender melhor qual é o alcance da experiência da alteridade para a consciência.

A liberdade não é, tal como Sartre a pretende fazer passar, apenas a capacidade da consciência de se furtar a qualquer determinação, de permanecer um nada para lá de toda e qualquer determinação eventual do seu ser, não é apenas ter a sua existência como um objecto disponível. A liberdade é também a capacidade de se entregar a esse mesmo ser, de o aceitar e de, através da acção, se colocar em sintonia com ele e não sempre em dissonância, como é o caso da consciência, tal como é concebida por Sartre. Outrem mostra à consciência que é possível realizar o seu ser de forma consistente, o seu ser próprio, o seu ser sujeito, apresentando-lhe não-teticamente, fazendo-a experienciar o que esse ser é.

31 E.N., p. 324. 
Vamos por partes. Tal como vimos, a concepção da consciência como Para-si conduz a uma inconsistência de ser da consciência, inconsistência que, no nosso ponto de vista, pode ser superada com a entrada em cena de outrem. O surgimento de outrem no seio da consciência fá-la experienciar uma dimensão do seu ser que lhe escapa e que ela é concretamente. No entanto, isto não significa que outrem vise a consciência enquanto objecto; pelo contrário, ele visa-a, por intermédio da sua liberdade vista como entrega, como doação, enquanto sujeito que ela é. A perturbação que se instala no interior da consciência é a atestação sentida de um ser que se situa, relativamente à consciência, numa transcendência, mas um ser que é positivo e não apenas um poder de negação, um nada.

Assim, o ser da consciência que é perspectivado por outrem não é uma totalidade em si, uma coisificação da consciência, mas um ser próprio, um ser sujeito que caracteriza a consciência, que lhe confere os seus traços únicos e o seu carácter inaudito. Se é verdade que a entrada em cena de outrem provoca um estremecimento na consciência, uma solidificação e um assombramento, não é menos verdade que isso não significa que a consciência se torne num objecto. Significa apenas que o seu ser tem uma certa positividade e que se constitui como um elemento sui generis - e não um nada - em que surgem os objectos e o mundo enquanto totalidade concatenada de significações. A entrada em cena de um outro sujeito sujeita a consciência, mostrando-lhe não-teticamente aquilo que ela não é - devido a essa liberdade vista como capacidade desagregadora - e aquilo que ela deve ser, não no sentido moral, objectivamente tomado, mas do ponto de vista ético, do ponto de vista de um habitar um elemento, o seu ser, que tem o seu fundamento fora de si, num outro.

Este modo de conceber a consciência, como relação a outrem, não reduz em nada a sua liberdade e a sua espontaneidade, pois a sua existência permanece sendo um problema abordado livremente. Não implica ainda a introdução de uma opacidade no interior da consciência, pois o $e u$, que é o protagonista deste ser, não é um habitante da consciência no sentido de coisa; ele habita-a como uma interioridade que ela não conhece, mas que vive, embora não como sujeito ontológico, mas como sujeito ético, que não se faz ser senão na relação a outrem e enquanto essa relação mesma.

Só esta dimensão do ser da consciência pode justificar a sua concepção como carência ou como desejo: se é verdade que a consciência é carência, ela é-o de um ser seu, de um ser que seja pura subjectividade e que não esteja prisioneiro de uma existência abordada pela liberdade pessoal como obstáculo ou problema, mas que se entregue livremente a essa existência através da aceitação, do acolhimento. Se é verdade que a consciência é desejo, ela é-o porque é desejo de outrem, é um projectar-se desiderativo para outrem num movimento de procura do fundamento do 
seu ser, um desejo que é inesgotável e que aumenta de intensidade quanto mais a consciência se procura fundar.

Sartre exige que a relação a outrem seja concreta e que, portanto, outrem possa ser visado como sujeito para a consciência, o que se revela impossível e, por essa razão, caímos na disjunção na passagem supracitada: se outrem tem uma existência e essa existência é um facto incontestável, a relação da consciência com ele está votada ao fracasso, o encontro de consciências é impossível porque cada intenção é percorrida por uma objectivação que solidifica outrem, não permitindo a sua manifestação subjectiva, o mesmo acontecendo com a consciência se outrem a visa concretamente.

No entanto, esta disjunção não permite ver outrem enquanto outro, apenas enquanto uma versão alterada do mesmo. Sartre projecta, aqui, o ponto de vista do próprio sobre o ponto de vista do outro, votando ao fracasso não apenas a relação entre consciências conforme é por si vista, mas as suas próprias teses. A procura de uma relação concreta com outrem no mundo é disso exemplo: Sartre afirma a permanência do carácter meramente provável da presença ao mundo de um humano, pois a sua doação à consciência dá-se sempre do ponto de vista objectual e, assim, como não-consciência. No entanto, Sartre esquece aqui que a ausência, o modo como outrem surge no mundo, não se refere apenas à existência de uma outra consciência no mundo, sem que uma relação a essa consciência seja possível, mas a essa relação enquanto o Possível ele mesmo, pois configura uma modalidade do ser da consciência, ou melhor, o seu ser mesmo, que se caracteriza por uma antecipação do sentido desse objecto que surge aí no mundo, não podendo ser dito, em sentido próprio, objecto, pois ele é sempre visado como sujeito, embora um sujeito ausente. E se essa atribuição de consciência tem um carácter provável, tem-no apenas no sentido de, inicialmente e sem recorrermos à análise posterior, ser uma adesão da consciência enquanto sujeito, mas uma adesão fundada na certeza antecipada da existência de outrem, dada enquanto afectividade e desejo no seio da consciência.

A relação da consciência ao ser-aí de outrem é uma relação afectiva e não de conhecimento, e é só por exigir a contemporaneidade da presença de outrem e da consciência própria, através de uma concepção limitada da presença, que Sartre pode afirmar que essa é uma relação impossível. A relação com outrem é possível, ela é o que constitui o Possível enquanto dimensão futurante da consciência, e só porque Sartre tem uma concepção do ser e da realidade muito estreita é que pode dizer que ela é impossível, esquecendo que esta possibilidade é bem real e, tendo em conta que todas as acções da consciência visam um espaço humano, é mesmo a mais real de todas. 
Queremos ainda reiterar a tese que afirma que a consciência é uma criação do nada, mas esse nada é a liberdade de outrem, não enquanto capacidade negativa de se colocar fora da relação, mas enquanto doação, enquanto entrega de si e da sua liberdade à consciência, criando-a, dando-lhe um ser próprio através dessa entrega mesma e fazendo-a responsável não só do seu ser, mas de outrem, na medida em que um esquecimento ou uma não-relação a este último implica um esquecimento de si. É enquanto relação a este outro que a consciência é.

É um facto que a consciência só é enquanto aparece, e isso pode induzir-nos, tal como a Sartre, a confundir este seu aparecer com o seu ser. Contudo, se a consciência parece ser Para-si, na medida em que é relação não-tética a si enquanto relação tética aos objectos, ela é-o apenas ilusoriamente: a consciência é, sempre e também, para um outro enquanto este contém o segredo do seu ser.

Em conclusão, vimos como o eu da consciência se dá como uma experiência íntima, como uma transcendência absoluta que, paradoxalmente, se deve à sua imanência ou proximidade à consciência e que, por essa razão, the escapa infinitamente, não se deixando nunca tematizar na sua totalidade. Essa experiência afectiva é dada à consciência pela entrada em cena de outrem, de uma outra consciência, de um outro si que aqui tentámos mostrar como mal problematizada por Sartre e que tentámos remeter à sua dimensão de alteridade genuína.

Nas primeiras páginas deste texto abordámos o modo como o ser da consciência, o seu Si, escapa permanentemente a todas as tentativas de objectivação e vimos como a redução desse Si a um Nada pela parte de Sartre se revestia de dificuldades inultrapassáveis, pois esquecia a positividade de ser da consciência a partir da qual esse Nada, enquanto fuga à tematização e carência de ser, poderia surgir. Estamos agora em condições de afirmar que, se o Si da consciência não coincide com esta, é porque ele permanece outro relativamente a esta, e já vimos como essa experiência da alteridade, tomada no seu sentido pleno, pode significar uma relação da consciência com um ser que é o seu e que ela não é ainda.

Por outras palavras, a alteridade do ser da consciência ou Si está ligada a uma dimensão afectiva e, por sua vez, relacionada com o surgimento do eu da consciência. Assim, não se vêem impedimentos para que essa concepção da consciência como uma espécie particular de afectividade, como desejo de um ser que lhe é transcendente, não possa ser afirmada. Queremos com isto dizer que é logo no plano não-tético que a consciência tem um eu, embora este só surja após a entrada em cena de outrem, o que significaria que outrem é o ser da consciência e que, por isso, nunca é objecto e que o eu lhe permanece transcendente, ainda que presente desde o início da sua actividade de relação ao outro que é o fundamento do seu ser. 
Mas não entramos aqui em contradição ao afirmar que outrem nunca é objecto para a consciência, após o que foi aqui exposto? A resposta é: não!

Efectivamente, ver supostamente o outro como objecto está sempre fundado numa antecipação da sua subjectividade e da subjectividade da própria consciência, ou seja, numa relação intersubjectiva fundante. De facto, nem o eu nem o outro são, desde logo, objectos, pois toda a suposta objectivação conhecedora do outro ou do eu pressupõe um encontro subjectivo que invalida, desde logo, a sua redução a objectos. Se é verdade que o eu pode ser objecto, é já como um eu degradado e não como esse eu que nasce dessa relação entre sujeitos e que pode ser assim dito propriamente.

A experiência da alteridade mostra à consciência, desde logo e originariamente, aquilo que ela pode e deve ser, e esse ser tem uma positividade que permanece outra para um eu concreto, não um eu meramente provável. Outrem é o ser que a consciência tem a possibilidade de ser se conseguir superar as limitações que a facticidade lhe impõe e, assim, a experiência da alteridade tem o sentido de experiência dos limites com vista à sua superação para alcançar uma dignidade de ser superior. Como tal, é como antecipação e projecto, como desejo, como afectividade, que a relação ao outro tem lugar, como pura relacionalidade despida de máscaras e não como conflito dialéctico, tal como Sartre tenta mostrar com uma argumentação por vezes muito convincente. Pensamos que isso fica aqui demonstrado.

\begin{abstract}
This paper intends to give a critical reading of Jean-Paul Sartre's treatment of inter-consciousness relationship as presented in his work L'être et le néant, namely in the chapter L'existence d'autrui. Our main objective is to understand the treatment Sartre gave the referred issue in that particular work, but also to show that his theoretical standpoint falls short on a true determination of the meaning of the experience of Otherness for consciousness. Our method for approaching Sartre's views stands on a detailed reading of the author's own analyses, trying to show their limited scope and providing a different, less conflictual treatment and interpretation for the presented data.

In Sartre's view, consciousness (the Pour-soi, as he calls it, i.e., non-positional consciousness) is not inhabited by an ego, that is, it doesn't have an ego until one becomes an object to it, similar to the remaining objects of the world, which occurs with the Other's entry in the world. That being, Sartre's fundamental problem is to know how is it possible for consciousness to constitute an ego as an object - as an object among other objects, but whose experience is, for consciousness, different from the one it makes of all other objects -, and, on a
\end{abstract}


second step, to state its identity with that ego, i.e., to be that ego, without loosing, in the process, its subjective spontaneity and freedom. Taken as a subject/object kind of relation, as Sartre affirms it, the inter-consciousness relationship is condemned to failure, doomed to be a permanent struggle for domination of one over an other.

Our analysis of the sartrian data as put forward in L'Etre et le néant will show that Sartre's thesis about inter-consciousness relationship is one-sided and that a more comprehensive interpretation of the above-mentioned relationship is possible, an interpretation based in the view that envisaging the Other as an object is founded on an anticipation of its subjectivity and of consciousness' own subjectivity, that is, on a founding intersubjective relationship. According to our viewpoint, if it is true that an ego can be an object, it is already as a degraded ego and not as the ego properly said, born out of a relationship between subjects.

The experience of Otherness shows consciousness, originally and immediately, what it can and should be, and that being has a positivity that remains an other for a concrete, knowable ego. That founding experience, which takes place at an affective level, has the meaning of an experience of the limits which, when surpassed, will allow consciousness to reach a higher dignity of being. Therefore it is as anticipation and project, as desire, as afectivity, that the relationship to an other takes place, as a pure relationality without masks, and not as a dialectical conflict, as Sartre intends to show with his occasionally convincing arguments. 